\title{
USE OF META-NETWORKS TO EVALUATE KEY AGENTS, KNOWLEDGE AND RESOURCES IN THE PLANNING OF CONSTRUCTION PROJECTS
}

\section{G. ŚLADOWSKI ${ }^{1}$}

The article proposes a new approach to the identification of key agents, knowledge and resources required to complete tasks being performed as a part of construction projects. The author used the concept of meta-networks to model the relations between agents, knowledge, resources and tasks of a project. Up until now, the identification of key means of production employed a measure of performance of the project that was modelled using a metanetwork. However, this measure is limited as it does not take into consideration the significance of individual tasks or the relations between them. The author thus proposed a structural modification of the performance measure for the purposes of identifying key agents, knowledge and resources of a planned project. A case study analysis has confirmed the application potential of the proposed approach. In practice, the results that were obtained can aid planners in evaluating the performance of a project's plan. Information about key agents, knowledge and resources can constitute the basis for drafting alternative plans which would be more resistant to failure due to the possible loss of key means of production over the course of carrying out a project.

Keywords: Meta-Network Analysis (MNA), Dynamic Network Analysis (DNA), planning construction projects, refurbishment of historical structures.

\section{INTRODUCTION}

Construction projects are closed technological and organisational systems, whose timeframes are clearly defined by a beginning and an end [1]. Every construction project is unique and is being

\footnotetext{
${ }^{1} \mathrm{PhD}$, Eng., Cracow University of Technology, Faculty of Civil Engineering, Institute of Construction Management, gsladowski@L3.pk.edu.pl
} 
carried out under different conditions in a complex environment, with its participants often being various temporary organisations that engage knowledge and other resources in order to accomplish their tasks.

One of project management's significant aspects is planning, the quality of which determines the effectiveness of the carrying out of a project. Most problems that appear during the stage of carrying out a project are caused by poor planning or even by the lack of planning overall [2].

Traditional approaches to project planning such as, for instance, the CPM method (Critical Path Method), or its probabilistic variant_-PERT (Program Evaluation and Review Technique)—focus only on the tasks and the relations between them. Dependencies between organisations, knowledge, machinery, materials and tasks, despite affecting the performance of a project, are not analysed in these cases [3].

For the past two decades there has been a marked increase in interest in social networks (SNA) in the construction sector and in the context of their application to the analyses of interpersonal relations both within and between organisations in the planning and carrying out of construction projects (e.g.[4, 5, 6]). However, these analyses focused solely on interactions between the participants of a project and did not identify direct relations between these entities with the tasks of a project, nor did they take into consideration the dependencies between these tasks.

It was only in [7] that the authors proposed an analysis of the relations between the participants and tasks of a construction project in the context of identifying communication between these participants. The authors highlighted that an integration of the methods of social network analysis with the analysis of task networks makes it possible to effectively plan and manage construction projects. In the work [8] its authors stressed that the analysis of the interactions between the participants of a construction project and its tasks should be expanded to include interaction with available knowledge and resources (e.g. machinery and construction materials) required to carry out a given project. In order to so, for the purposes of modelling and analysis, the authors proposed the use of the concept of meta-networks developed by $[9,10,11]$ and based on the integration and analysis of numerous networks simultaneously, with said networks determining the dependencies between the elements of the analysed system. Meta-networks were used earlier to model and analyse problems such as fighting terrorism [12], healthcare [13] and increasing resilience as a reaction to the effects of disasters [14]. The possibilities of the application of meta-networks along with their dynamic analysis in the planning and management of construction projects have started to be investigated only recently and so far only a small amount of publications have been written on the subject. The first such works concerned the application of meta-networks in analysing the coherence 
of connections between agents (participants), knowledge and tasks within construction projects and to rate the performance of these projects on the example of the construction of a chain of car dealerships in China [8, 15]. In the work [16], the authors employed meta-networks to analyse critical agents, knowledge and resources, as well as rate gaps in a plan through the use of the performance of a planned construction project under threat from perturbations. The work [17] in turn analysed the susceptibility of a construction project to threats and its capacity for adaptation. In the work [18] the authors, through using meta-networks to perform three case studies, investigated the correlation between the susceptibility of a project to threats and the performance of its plan, in addition to the correlation between a project's level of susceptibility and exposure to uncertainty and organisational complexity.

In the aforementioned publications, as a part of rating the structural coherence of planned projects, as well as to determine key agents, knowledge and resources required to complete the project being modelled by the meta-network, the authors used the performance measure proposed in [19]. However, this measure (which defines a percentage of tasks that can be completed because agents, knowledge and resources have been assigned to them) has a significant limitation as it does not take into consideration the significance of individual tasks, nor the relations between them. There is thus a need to modify this measure for the purpose of analysing the coherence of a meta-network or analyse key agents, knowledge and resources in the planning of construction projects.

The goal of the article is to include the effect of the significance of a project's tasks and the codependencies between them in the rating of key agents, knowledge and resources of a project planned using meta-networks. The application potential of the proposed approach will be presented on the example of the project of the Refurbishment of the Outer Courtyard along with access roads at Wawel Castle.

\section{META-NETWORK CHARACTERISTICS}

\subsection{META-NETWORK MODEL STRUCTURE}

We are given a network based on a graph, which is composed of two sets of known units, $U$ and $V$, and a set of relations: $E \subset U \times V$. For $i \in U$ and $j \in V$ element $e=(i, j)$ means that there exists a relationship between units. These units and the relations between them are represented by a set of networks called a meta-network [8]. 
The structure of the network can be presented with the use of a matrix, in which elements determine relations between the individual nodes of a network.

The structure of the meta-network integrates different types of networks. Table 1 presents a metamatrix of a sample meta-network containing four basic types of nodes, which make it possible to generate 10 types of networks. We can find other concepts of nodes in literature [11], such as events, organisation, etc., of which there are 10 in total and which make it possible to generate as many as 55 types of networks within a meta-network.

Table 1 Meta-matrix containing 10 basic types of networks which define the structure of a meta-network

\begin{tabular}{|c|c|c|c|c|}
\hline $\mathrm{U}_{U}^{V}$ & Agent & Knowledge & Resource & Task \\
\hline Agent & $\begin{array}{c}\text { Social Network } \\
(A A) \text { : Who works } \\
\text { with whom }\end{array}$ & $\begin{array}{l}\text { Agent knowledge } \\
\text { access network } \\
(A K) \text { : } \\
\text { Who knows what }\end{array}$ & $\begin{array}{l}\text { Agent resource } \\
\text { access network } \\
(\text { AR): Who uses } \\
\text { what machinery } \\
\text { and what } \\
\text { materials do they } \\
\text { use }\end{array}$ & $\begin{array}{l}\text { Agent task } \\
\text { assignment } \\
\text { network }(A T) \text { : } \\
\text { Who is assigned } \\
\text { to which task }\end{array}$ \\
\hline Knowledge & & $\begin{array}{l}\text { Knowledge } \\
\text { network }(K K) \text { : } \\
\text { What are the } \\
\text { dependencies } \\
\text { between } \\
\text { knowledge }\end{array}$ & $\begin{array}{l}\text { Network of } \\
\text { knowledge needed } \\
\text { for resources to be } \\
\text { used }(K R) \text { : What } \\
\text { knowledge is } \\
\text { necessary for the } \\
\text { use of which } \\
\text { resource }\end{array}$ & $\begin{array}{l}\text { Knowledge task } \\
\text { assignment } \\
\text { network }(K T) \text { : } \\
\text { What knowledge } \\
\text { is assigned to } \\
\text { which task }\end{array}$ \\
\hline Resource & & & $\begin{array}{l}\text { Resource network } \\
(R R) \text { : } \\
\text { What are the } \\
\text { dependencies } \\
\text { between } \\
\text { resources }\end{array}$ & $\begin{array}{l}\text { Resource task } \\
\text { assignment } \\
\text { network }(R T) \text { : } \\
\text { Which resources } \\
\text { are assigned to } \\
\text { which tasks }\end{array}$ \\
\hline Task & & & & $\begin{array}{l}\text { Task network } \\
(T T) \text { : What are } \\
\text { the dependencies } \\
\text { between tasks }\end{array}$ \\
\hline
\end{tabular}

Networks which contain one type of node, e.g. (AA): a social network (SNA), are called singlemode networks, while in the case of two types of nodes, e.g. (AK), they are called two-mode networks. A meta-network is a multi-mode network, because it contains at least two types of nodes. 


\subsection{STRUCTURAL ANALYSIS OF THE MODEL-BASIC MEASURES}

In subject literature we can find many measures of networks, which provide important information about the system that is being modelled [19]. Below is a presentation of the basic measures of structural analysis for single and multi-mode networks.

Basic symbols used in formulae:

$A$ - square relationship matrix for a single-mode network (e.g. relations between agents)

$A K$ - relationship matrix for a two-mode network (e.g. relations between agents and knowledge)

$|A|$ - number of nodes within a network

$A(i, j)$ - The entry in the $i^{t h}$ row and $j^{t h}$ column of the matrix

$A(i:)$ - The $i^{\text {th }}$ row vector of a matrix

$A^{\prime}$ - Transpose of a matrix

The basic measures for single and multi-mode networks are as follows:

The density of a network is the quotient of the number of existing relations and the number of all potential relations within a network [20]:

$$
\Delta=\frac{l}{n(n-1)},
$$

Where: $\Delta$ is the density of a network, $n$ is the number of nodes within a network.

The centrality degree for a single-mode network is the number of connections between a single node and other nodes within a network. Within centrality, we have an in-degree and an out-degree of a node. These are the numbers of inbound and outbound relations of a node, respectively. This measure has found particular use in social networks (SNA) in the interpretation of the role of agents within an organisation [20]:

$$
C_{D}^{1}(x)=\frac{\text { in-degree }(x)+\operatorname{out}-\operatorname{degree}(x)}{2(n-1)},
$$

Where: $C_{D}^{1}(x)$ is the degree of centrality, $x$ is a specific node within the graph, $n$ is the number of nodes within the graph. 
The degree for two-mode networks defines the number of connections between an agent and knowledge and between an agent and the resources within the analysed system, respectively [20]:

$$
\text { for } A K \quad d_{i}=\frac{\sum_{j=1}^{|K|} A K(i, j)}{|K|}, \text { for } A R \quad d_{i}=\frac{\sum_{j=1}^{|K|} A R(i, j)}{|K|} \text {, }
$$

The degree for multi-mode networks is the number of connections between an agent and other agents within the system, as well as with knowledge, resources and tasks that are performed by said agent [19]:

$$
c_{i}=\frac{\sum_{j=1, j \neq i}^{|K|} A A(j, i)+\sum A K(i,:)+\sum A R(i,:)+\sum A T(i,:)}{(|A|-1)+|K|+|R|+|T|},
$$

For the purposes of building large meta-networks and their structural analysis, we can use a tool called „The Organizational Risk Analyzer” (ORA) that has been developed at the Center for Computational Analysis of Social and Organizational Systems (CASOS) by Kathleen Carley [21].

\subsection{New Concept of the Performance Measure for the Purposes of IDENTIFYING KEY NODES WITHIN A META-NETWORK MODEL}

In publications on the subject of the use of meta-networks in the management of construction projects, [8], [14-18] for the purposes of rating the structural coherence of planned projects, in addition to determining key agents, knowledge and resources required in the completion of the project modelled by the meta-network, the authors used the performance measure proposed in [19]. This measure defines the percentage of a project's tasks that can be completed because agents with proper knowledge and resources (e.g. machinery, construction materials) have been assigned to carry them out. Calculating performance for a meta-network requires the use of the following formulae:

The number of tasks that cannot be completed due to the lack of necessary knowledge that should be at an agents' disposal for the purposes of completing said tasks:

$$
N_{K}=\left(A T^{\prime} \cdot A K\right)-K T^{\prime},
$$




$$
S_{K}=\left\{t \mid t \in T, \exists k: N_{K}(t, k)<0\right\},
$$

The percentage of tasks that can be completed because agents and the knowledge required for their completion are available:

$$
T C_{K}=\frac{|T|-\left|S_{K}\right|}{|T|}
$$

By analogy, the number of tasks that cannot be completed due to the lack of required resources that agents should have at their disposal in order to complete said tasks:

$$
\begin{aligned}
& N_{R}=\left(A T^{\prime} \cdot A R\right)-R T^{\prime}, \\
& S_{R}=\left\{t \mid t \in T, \exists k: N_{R}(t, r)<0\right\},
\end{aligned}
$$

The percentage of tasks that can be completed thanks to the availability of the agents and resources required for their completion:

$$
T C_{R}=\frac{|T|-\left|S_{R}\right|}{|T|},
$$

In order to define key agents, knowledge and resources needed to complete the project modelled by the meta-network, we need to successively remove the node of a given agent and, separately, the connection of a knowledge or resource node with those of agents and determine the performance measure for the resultant meta-network each time (literature). The higher the percentage of the completion of tasks, the less key a given agent, knowledge or resource is.

The performance measure determined in the manner presented above (formula 1.3 and, consequently, 1.6) has a significant limitation, as it does not take into consideration the significance of each of the tasks, as well as the significance of the relations between them. In the planning of construction projects, information about the number of tasks that can be completed requires expanding to include information concerning the completion deadlines for these tasks, in addition to whether or not they are on a project's critical path. For instance, the inability to complete one critical task that is planned for completion as one of the first tasks in a project, will make it impossible to complete the successive tasks, which is a worse planning flaw than the inability to complete a greater amount of tasks that are not critical and whose completion deadlines come later. During the commencement of carrying out a project, any shortages in the availability of agents, knowledge and resources for tasks that are not being carried out first can be addressed (before their start). 
Thus, in order to modify this measure, the author of this article proposes that the following steps be taken:

Step 1. Formulae $(1.1,1.2)$ should be employed and, by analogy, $(1.4,1.5)$

Step 2. For TT networks of dependencies between tasks, the furthest initiation times for each task (there is no spare time in such a deadline schedule, which means all tasks will become critical) should be determined using the CPM (Critical Path Method).

Step3. Among tasks from set $S_{K}$ and, by analogy, from set $S_{R}$, which cannot be completed regardless of their number, the tasks planned to be completed first (in accordance with the longest initiation times) determine the performance of the plan.

\section{CASE STUDY}

\subsection{PRoJeCt DESCRIPTION}

In order to present the proposed method of identifying key participants, specialist knowledge, machinery and materials necessary for the completion of a project, the author chose one of the projects that were being carried out in the years 2009-2012 at Wawel Hill in Krakow. The project involved the refurbishment of the Outer Courtyard along with its access roads. The scope of refurbishment work on the Outer Courtyard included replacing underground infrastructure, replacing the substructure of the surface course of stone pedestrian and vehicular paths, securing any archaeological artefacts and the conservation of street furniture, see Fig. 1. The refurbishment work began with surveying work for the purposes of replacing the underground infrastructure. In order to correctly perform the surveying, knowledge concerning the placement of existing underground infrastructure and previously surveyed archaeological artefacts was required. The next step involved the performing of excavation work in the form of trenches for the purposes of replacing elements of the underground infrastructure (water and sewerage pipes, power and telecommunications lines). The excavation was performed manually under strict archaeological supervision. Simultaneously to the excavation, sandstone surface tiles were being dismantled using special self-propelled vacuum lifters and where afterwards transported off-site for the purposes of evaluating their suitability and preparation for reuse. Independently of the work associated with the replacement of the underground infrastructure, work commenced on deepening the road construction trench for the purposes of constructing the designed courses of the new surface. Archaeological artefacts uncovered during the excavation were 
appropriately secured on the basis of specialist conservation knowledge about the possible variants of performing such work. Subsequent work was associated with building the concrete footing for the borders and curbs of the designed surface. Prior to placing the structural courses of the subbase, analyses of the load-bearing capacity and compactness of the subgrade course were performed in order to select the appropriate method of its reinforcement, which required the designer to possess specialist knowledge on the possible variants of reinforcement. After completing the structural layers of the subbase, work commenced on laying the wearing course composed of sandstone tiles. According to conservation guidelines, the wearing course composed of tiles was constructed while taking into consideration the maximum possible amount of reclaimed tiles from amongst those that had previously been dismantled.

The constraints resulting from carrying out work on a historical structure, the necessity to perform specialist work and its uncertain character because of a poorly identified base (geotechnical parameters, the existing underground infrastructure, archaeological artefacts) made this project difficult to plan and carry out $[22,23]$. Information about key participants, specialist knowledge, machinery and materials is particularly essential already at the start of such an endeavour. The lack of a given participant or their access to specialist knowledge or resource affects the performance of the entire plan and the carrying out of such a project.
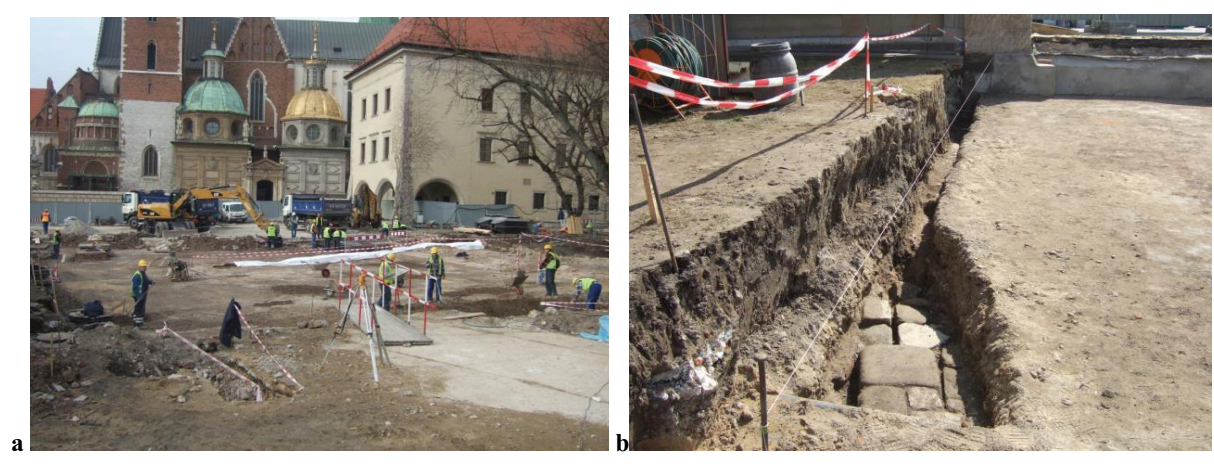

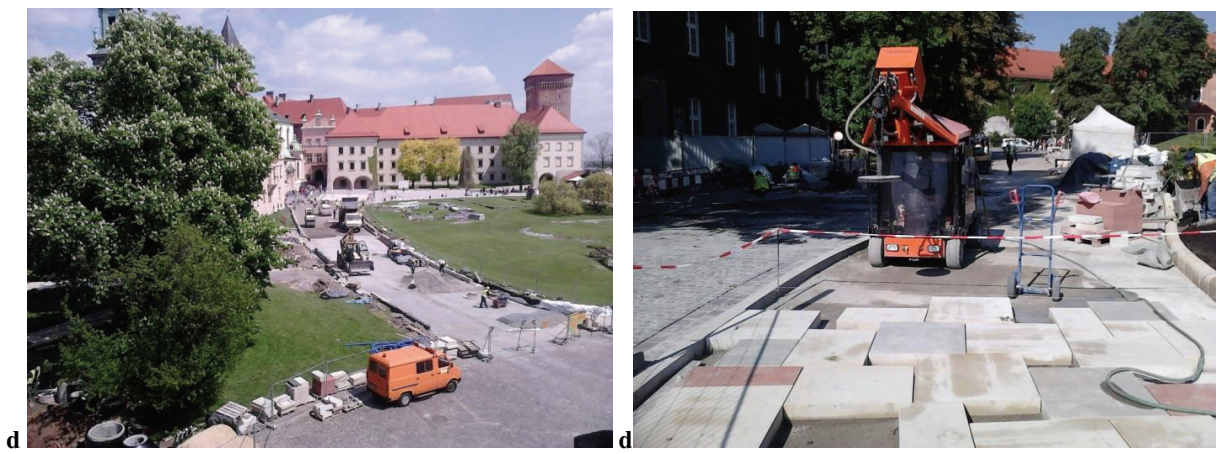

Fig. 1. Fragment of the photographic documentation of refurbishment work performed on the Outer Courtyard at Wawel Castle: (a) view of the bottom of the excavation trench; (b) uncovering of archaeological artefacts; (c) view of the aggregate subbase course being laid; (d) wearing course out of sandstone tiles, source: original photographic documentation.

\subsection{META-NETWORK MODEL OF THE PLANNED PROJECT}

In order to construct a meta-network of dependencies between tasks, participants (agents) of a project, specialist knowledge, as well as machinery and materials, the first step was the preparation of single and two-mode network models, for which the basic measures of these networks were calculated, such as: density and centrality degree. Figures 2-6 show 5 out of 9 created networks. Afterwards, the networks in question were combined by assigning agents, knowledge and resources to each task. The author then determined the density and centrality degree (fig. 7) for the metanetwork (multi-mode network) obtained in this manner. In order to build the network models of the analysed project and calculate the basic structural measures, the author used the Organisational Risk Analyser (ORA) application. 


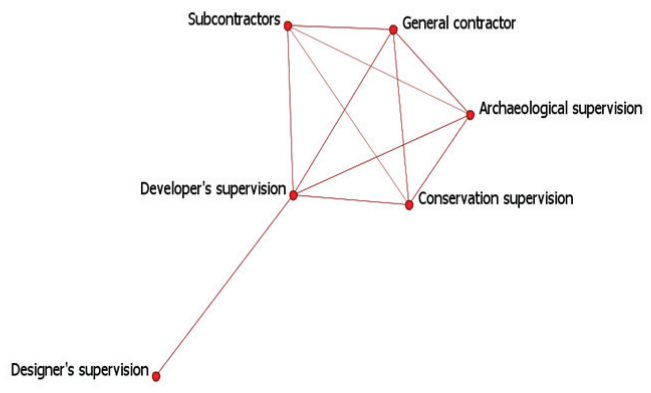

- Agent o Knowledge $\triangle$ Resource ${ }^{\text {Task }}$

Fig. 2. Type network AA. Network density is 0.667 . The maximum centrality degree is 100.000 (Developer's supervision).

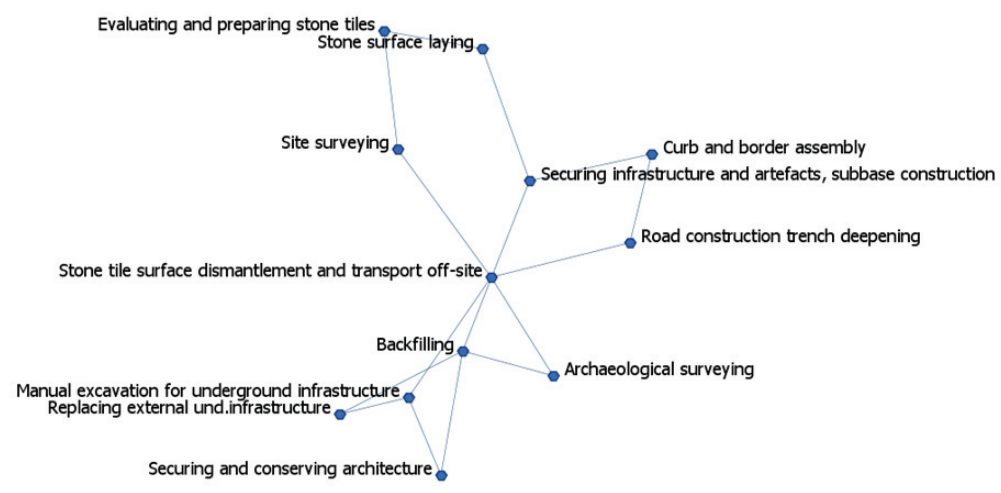

- Agent 0 Knowledge $\triangle$ Resource

Fig. 3. Type network TT. Network density is 0.114 . The maximum centrality degree is 18.182 (Stone tile surface dismantlement and transport off-site and Backfilling). 


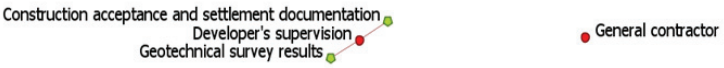

Agent 0 Knowledge $\triangle$ Resource

Task

Fig. 4. Type network AK. Network density is 0.222 . The maximum degree is 0.993 (Designer's supervision).

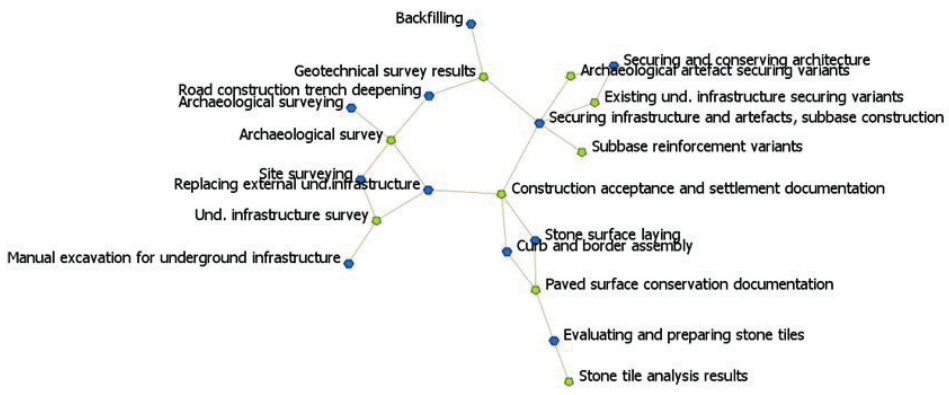

Stone tile surface dismantlement and transport off-site

Fig. 5. Type network KT. Network density is 0.213. The maximum degree 0.993 (Archaeological survey and Construction acceptance and settlement documentation). 


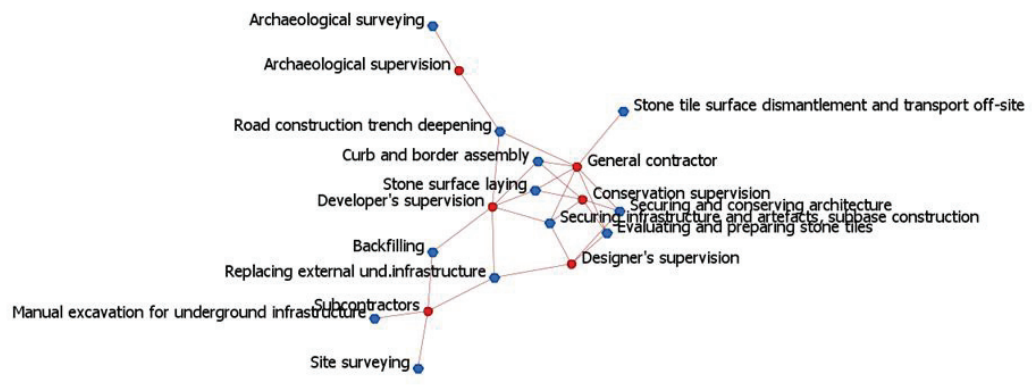

- Agent ${ }^{\text {Knowledge }} \Delta$ Resource Task

Fig. 6. Type network AT. Network density is 0.389.The maximum degree is 0.993 (General Contractor).

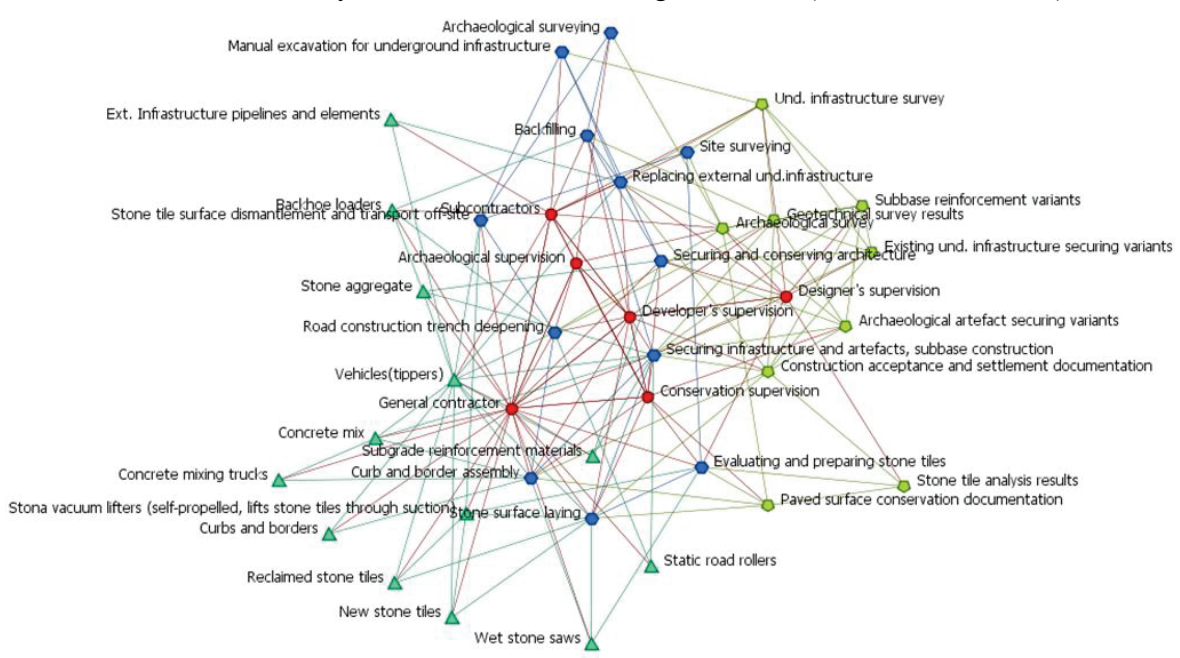

Agent $0^{\text {Knowledge }} \triangle$ Resource ${ }^{\text {Task }}$

Fig. 7. META-NETWORK project. Meta-network density is 0.198 . The maximum degree is 0.559 (General Contractor). 


\subsection{IDENTIFICATION OF KEY AGENTS, KNOWLEDGE AND RESOURCES}

In order to determine key agents, knowledge and resources required to complete the planned project, the author first successively removed individual agent nodes from the meta-network and calculated the performance measure modified by the author for the resultant meta-network. The same procedure was used in the case of knowledge and resource nodes, with the difference being that the connections that were removed were those between the nodes in question and agent nodes. The results of the analysis have been presented in tables 2, 3 and 4. Key agents, knowledge and resources have been marked in red. They are subcontractors in the infrastructure industry (water and sewage, energy and teletechnical networks), knowledge about previously discovered archaeological relics, vacuum lifters for stone slabs (self-propelled). The tasks that could not be started due to the unavailability of a given agent, piece of knowledge or resource required for their completion have been marked with an $\mathrm{X}$.

Table 2. The key agent in the context of completing the tasks of the planned project.

\begin{tabular}{|c|c|c|c|c|c|c|c|c|}
\hline TASK & 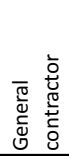 & 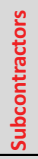 & 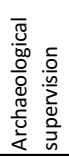 & 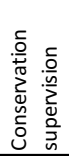 & 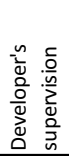 & 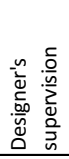 & 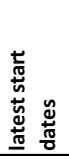 & 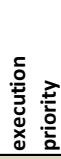 \\
\hline Site surveying & & $\mathrm{x}$ & & & & & 0 & 1 \\
\hline Stone tile surface dismantlement and transport off-site & $\mathrm{x}$ & & & & & & 1 & 2 \\
\hline Road construction trench deepening & $\mathrm{x}$ & & $\mathrm{x}$ & & $\mathrm{x}$ & & 31 & 6 \\
\hline Curb and border assembly & $\mathrm{x}$ & & & $\mathrm{x}$ & $\mathrm{x}$ & & 36 & 7 \\
\hline Manual excavation for underground infrastructure & & $\mathrm{x}$ & & & & & 21 & 5 \\
\hline Archaeological surveying & & & $\mathrm{x}$ & & & & 16 & 3 \\
\hline Securing and conserving architecture & $\mathrm{x}$ & & & $\mathrm{x}$ & & $\mathrm{x}$ & 36 & 7 \\
\hline Replacing external und.infrastructure & & $\mathrm{x}$ & & & $\mathrm{x}$ & & 36 & 7 \\
\hline Backfilling & & $\mathrm{x}$ & & & $\mathrm{x}$ & & 46 & 8 \\
\hline Securing infrastructure and artefacts, subbase construction & $\mathrm{x}$ & & & $\mathrm{x}$ & $\mathrm{x}$ & $\mathrm{x}$ & 56 & 9 \\
\hline Evaluating and preparing stone tiles & $\mathrm{x}$ & & & $\mathrm{x}$ & & $\mathrm{x}$ & 20 & 4 \\
\hline Stone surface laying & $\mathrm{x}$ & & & $\mathrm{x}$ & $\mathrm{x}$ & & 91 & 10 \\
\hline Ranking of key Agents & 2 & 1 & 3 & 4 & 6 & 5 & & \\
\hline
\end{tabular}

Table 3. The key knowledge in the context of completing the tasks of the planned project. 


\begin{tabular}{|c|c|c|c|c|c|c|c|c|c|c|c|}
\hline KNOWLEDGE & 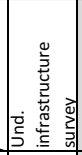 & 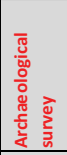 & 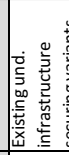 & 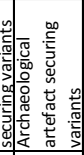 & 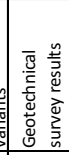 & 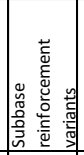 & 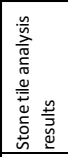 & 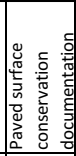 & 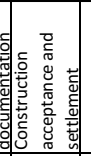 & 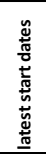 & 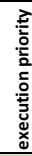 \\
\hline Site surveying & $\mathrm{x}$ & $\mathrm{x}$ & & & & & & & & 0 & 1 \\
\hline Stone tile surface dismantlement and transport off-site & & & & & & & & & & 1 & 2 \\
\hline Road construction trench deepening & & $\mathrm{x}$ & & & $\mathrm{x}$ & & & & & 31 & 6 \\
\hline Curb and border assembly & & & & & & & & $\mathrm{x}$ & $\mathrm{x}$ & 36 & 7 \\
\hline Manual excavation for underground infrastructure & $\mathrm{x}$ & & & & & & & & & 21 & 5 \\
\hline Archaeological surveying & & $\mathrm{x}$ & & & & & & & & 16 & 3 \\
\hline Securing and conserving architecture & & & $\mathrm{x}$ & $\mathrm{x}$ & & & & & & 36 & 7 \\
\hline Replacing external und.infrastructure & $\mathrm{x}$ & $\mathrm{x}$ & & & & & & & $\mathrm{x}$ & 36 & 7 \\
\hline Backfilling & & & & & $\mathrm{x}$ & & & & & 46 & 8 \\
\hline Securing infrastructure and artefacts, subbase construction & & & $\mathrm{x}$ & $\mathrm{x}$ & $\mathrm{x}$ & $\mathrm{x}$ & & & $\mathrm{x}$ & 56 & 9 \\
\hline Evaluating and preparing stone tiles & & & & & & & $\mathrm{x}$ & $\mathrm{x}$ & & 20 & 4 \\
\hline Stone surface laying & & & & & & & & $\mathrm{x}$ & $\mathrm{x}$ & 91 & 10 \\
\hline Ranking of key knowledge & 2 & 1 & 7 & 7 & 5 & 8 & 4 & 3 & 6 & & \\
\hline
\end{tabular}

Table 4. Key resource in the context of the completing the tasks of the planned project.

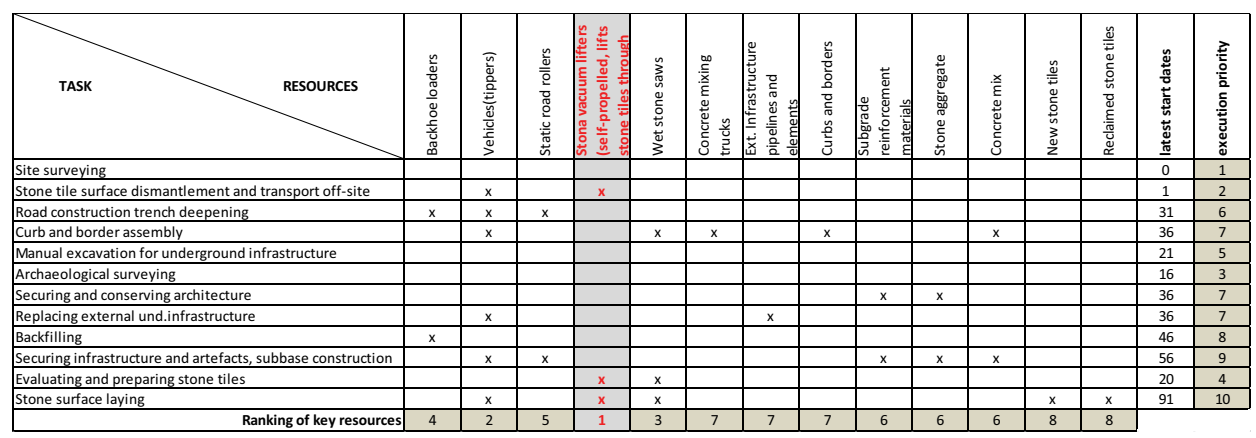

Based on the analysis presented above, we can see that the number of tasks that cannot be initiated due to the unavailability of a given agent, piece of knowledge or resource does not decide whether these means of production are key or not. The key status of an agent, piece of knowledge or resource is primarily decided by those tasks (from among the tasks that cannot be completed) which should be carried out first in accordance with the latest possible starting dates

\section{CONCLUSION}

The planning of construction projects is an essential function of management, because the quality of a plan or sometimes the lack thereof affects the performance of the completion of such a project. As a part of the planning of a project's tasks, planners should identify entities/organisations, 
knowledge and resources that are necessary for their completion. As a part of a systemic approach to project management, apart from classic, basic methods of planning and network analysis such as CPM/PERT (Critical Path method / Program Evaluation and Review Technique), the concept of meta-networks - which is still being developed in literature - which had its start with $[9,10,11]$ and is based on the integration and analysis of several networks simultaneously with each defining a given subsystem within the framework of the entire system under analysis. Meta-networks have found use in the analysis of such problems like fighting terrorism [12], healthcare [13] and increasing resilience in reaction to the effects of disasters [14]. We can currently observe an increase in interest in metanetworks in the construction sector. Several publications have been written on the subject, having found application mainly in the planning of construction projects [8], [14-18]. The article highlights the problem of identifying (with the use of meta-networks) key agents, knowledge and resources required to complete tasks being a part of a planned project. The structural analysis of this problem that was presented in literature was based on the measure of performance, which defines the percentage of tasks that can be completed thanks to the assigning of agents, knowledge and resources to carrying them out. However, this measure is limited because it does not take into consideration the significance of each task and of the relations between them. In this article the author proposed a modification of this analysis with the use of the classical CPM (Critical Path Method) method to determine priority tasks, which should have means of production assigned to them first. The analysis of key agents, knowledge and resources necessary to complete the planned tasks was performed by the author on the example of the refurbishment of the Outer Courtyard along with its access roads. The analysis of this example confirmed the justification for the proposed approach. In practice, the results that were obtained can aid planners in evaluating the performance of a project's plan. Information about key agents, knowledge and resources can constitute the basis for drafting alternative plans which would be more resistant to failure due to the possible loss of key means of production over the course of carrying out a project.

Simulations on detecting gaps within a project under threat from perturbations in accordance with the concept proposed in [16] for the presented concept of the measure of performance can be continued in the future.

\section{REFERENCES}

[1] Kapliński, O., „Wielowymiarowość problematyki inżynierii przedsięwzięć budowlanych” In: L. Czarnecki (Ed.) Innowacyjne wyzwania techniki budowlanej, Instytut Techniki Budowlanej, Warszawa, 601-619, 2017. 
[2] Trocki, M., Wyrozębski, P., „Planowanie przebiegu projektów”, Szkoła Główna Handlowa w Warszawie. Oficyna Wydawnicza, 2015.

[3] Engwall, M., „No project is an island: linking projects to history and context”, Research policy, 32(5): 789-808, 2003.

[4] Pryke, S. D., "Analysing construction project coalitions: exploring the application of social network analysis", Construction management and economics, 22(8): 787-797, 2004.

[5] Chinowsky, P., Diekmann, J., Galotti, V., "Social network model of construction", Journal of construction engineering and management, 134(10): 804-812, 2008.

[6] El-Sheikh, A., Pryke, S. D., "Network gaps and project success", Construction management and economics, 28(12): 1205-1217, 2010.

[7] Chinowsky, P., Taylor, J. E., Di Marco, M., "Project network interdependency alignment: New approach to assessing project effectiveness. Journal of Management in Engineering, 27(3): 170-178, 2010

[8] Li, Y. K., Qian, L. L., He, Q. H., Duan, Y. F.,"Meta-network Based Fitness Measurement of Projects Organization and Tasks Assignment. In Proceedings of the 17th International Symposium on Advancement of Construction Management and Real Estate (pp. 643-655). Springer, Berlin, Heidelberg, 2014.

[9] Carley, K. M., "Intraorganizational complexity and computation. The Blackwell companion to organizations", J. Baum, ed., Wiley Blackwell, NJ, 208-232, 2002a.

[10] Carley, K. M., "Computational organizational science and organizational engineering. Simulation Modelling Practice and Theory, 10(5-7): 253-269, 2002b.

[11] Carley, K. M., "Dynamic network analysis. In P. Pattison, K. M. Carley, \& R.Breiger (Eds.), Dynamic Social Network Modeling and Analysis Workshop Summary and Papers Washington”, D.C: National Academies Press, pp. 133-145, 2003.

[12] Carley, K. M.,“Dynamic network analysis for counter-terrorism”, Unpublished manuscript, 2005.

[13] Effken, J. A., Carley, K. M., Gephart, S., Verran, J. A., Bianchi, D., Reminga, J., Brewer, B. B., "Using ORA to explore the relationship of nursing unit communication to patient safety and quality outcomes", International journal of medical informatics, 80(7): 507-517, 2011.

[14] Zhu, J., Mostafavi, A., "Enhancing Resilience in Disaster Response: A Meta-Network Analysis Approach", In Construction Research Congress , (pp. 553-562), 2018.

[15] Li, Y., Lu, Y., Li, D., Ma, L., "Metanetwork analysis for project task assignment", Journal of Construction Engineering and Management, 141(12): 04015044, 2015.

[16] Zhu, J., Mostafavi, A., "An integrated framework for assessment of the impacts of uncertainty in construction projects using dynamic network simulation.” In 2015 ASCE International Workshop on Computing in Civil Engineering. Austin, TX, 2015.

[17] Zhu, J., Mostafavi, A., "Dynamic Meta-Network Modeling for an Integrated Project Performance Assessment under Uncertainty”, In Construction Research Congress , (pp. 2340-2350), 2016.

[18] Zhu, J., Mostafavi, A. "Characterization of the underlying mechanisms of vulnerability in complex projects using dynamic network simulation”, In Simulation Conference (WSC), 2017 Winter (pp. 2436-2447). IEEE, 2017.

[19] Reminga, J., Carley, K. M., "Measures for ORA (Organizational Risk Analyzer)”. Institute for Software Research School of Computer Science, Carnegie Mellon University, 22: 2003.

[20] Wasserman, S., Faust, K., "Social network analysis: Methods and applications", Cambridge university press, (Vol. 8), 1994

[21] „The Organizational Risk Analyzer” (ORA) (http://www.casos.cs.cmu.edu/projects/ora/software.php).

[22] Radziszewska-Zielina, E., Śladowski, G., Sibielak, M. „Planning the reconstruction of a historical building by using a fuzzy stochastic network", Automation in Construction, 84: 242-257, 2017.

[23] Radziszewska-Zielina, E., Śladowski, G. "Proposal of the Use of a Fuzzy Stochastic Network for the Preliminary Evaluation of the Feasibility of the Process of the Adaptation of a Historical Building to a Particular Form of Use", In IOP Conference Series: Materials Science and Engineering (Vol. 245, No. 7, p. 072029). IOP Publishing, 2017.

\section{LIST OF FIGURES AND TABLES:}

Table 1. Meta-matrix containing 10 basic types of networks which define the structure of a meta-network.

Tabela 1. Meta-macierz zawierająca 10 podstawowych rodzajów sieci, które określają strukturę meta-sieci.

Fig. 1. Fragment of the photographic documentation of refurbishment work performed on the Outer Courtyard at Wawel Castle: (a) view of the bottom of the excavation trench; (b) uncovering of archaeological artefacts; 
(c) view of the aggregate subbase course being laid; (d) wearing course out of sandstone tiles, source: original photographic documentation.

Rys. 1. Fragment Dokumentacji fotograficznej prac rewaloryzacyjnych Dziedzińca Zewnętrznego na Wawelu: (a) widok dna koryta robót ziemnych; (b) odsłaniane na bieżąco relikty archeologiczne; (c) widok układanej podbudowy z kruszywa; (d) warstwa ścieralna nawierzchni z piaskowca, źródło: własna dokumentacja fotograficzna.

Fig. 2. Type network AA. Network density is 0.667 . The maximum centrality degree is 100.000 (Developer's supervision).

Rys. 2. Sieć typu AA, Gęstość sieci wynosi 0.667 Maksymalny stopień centralności wynosi 100.000 (Nadzór inwestorski)

Fig. 3. Type network TT. Network density is 0.114 . The maximum centrality degree is 18.182 (Stone tile surface dismantlement and transport off-site and Backfilling).

Rys. 3. Sieć typu TT, Gęstość sieci wynosi 0.114. Maksymalny stopień centralności wynosi 18.182 (Rozbiórka nawierzchni z płyt kamiennych i wywiezienie z placu budowy oraz zasypanie wykopów)

Fig. 4. Type network AK. Network density is 0.222 . The maximum degree is 0.993 (Designer's supervision). Rys. 4. Sieć typu AK, Gęstość sieci wynosi 0.222. Maksymalny stopień wynosi 0.993 (Nadzór autorski)

Fig. 5. Type network KT. Network density is 0.213. The maximum degree 0.993 (Archaeological survey and Construction acceptance and settlement documentation).

Rys. 5. Sieć typu KT, Gęstość sieci wynosi 0.213. Maksymalny stopień wynosi 0.993 (Inwentaryzacja reliktów archeologicznych oraz dokumentacja odbiorowa i rozliczeniowa)

Fig. 6. Type network AT. Network density is 0.389. The maximum degree is 0.993 (General Contractor).

Rys. 6. Sieć typu AT, Gęstość sieci wynosi 0.389. Maksymalny stopień wynosi 0.993 (Generalny wykonawca).

Fig. 7. META-NETWORK. Meta-network density is 0.198 . The maximum degree is 0.559 (General Contractor).

Rys. 2. META-SIEĆ Gęstość sieci wynosi 0.198. Maksymalny stopień wynosi 0.559 ( Generalny wykonawca).

Table 2. The key agent in the context of completing the tasks of the planned project.

Tabela 2. Kluczowy agent w kontekście realizacji zadań planowanego przedsięwzięcia.

Table 3. The key knowledge in the context of completing the tasks of the planned project.

Tabela 3. Kluczowa wiedza w kontekście realizacji zadań planowanego przedsięwzięcia.

Table 4. Key resource in the context of the completing the tasks of the planned project.

Tabela 4. Kluczowy zasób w kontekście realizacji zadań planowanego przedsięwzięcia. 


\section{WYKORZYSTANIE META-ŚIECI DO OCENY KLUCZOWYCH AGENTÓW, WIEDZY I ZASOBÓW W PLANOWANIU PRZEDSIĘWZIĘĆ BUDOWLANYCH}

Słowa kluczowe: Meta-Network Analysis (MNA), Dynamic Network Analysis (DNA), planowanie przedsięwzięć budowlanych, rewaloryzacja obiektów zabytkowych.

\section{STRESZCZENIE:}

W artykule zaproponowano nowe podejście do identyfikacji kluczowych agentów (uczestników), wiedzy i zasobów potrzebnych do realizacji zadań w ramach przedsięwzięć budowlanych. Do modelowania relacji pomiędzy agentami, wiedzą, zasobami oraz zadaniami przedsięwzięcia wykorzystano koncepcję meta-sieci. opracowanej przez $[9,10,11]$ i opartej na integracji i analizie wielu sieci równocześnie, które określają zależności pomiędzy elementami analizowanego systemu. Dotychczas do identyfikacji kluczowych środków produkcji wykorzystywana była miara wydajności (performance) modelowanego przez meta-sieć przedsięwzięcia, Jednak miara ta (określająca procent zadań które mogą być wykonane dzięki temu, że do ich realizacji są przypisani Agenci, wiedza i zasoby) ma istotne ograniczenie, gdyż nie uwzględnia ważności poszczególnych zadań jak również relacji pomiędzy nimi. Przykładowo, brak możliwości wykonania jednego zadania krytycznego, które planowane jest do realizacji jako jedno z pierwszych, uniemożliwi realizację kolejnych, co jest gorszym mankamentem planu niż brak możliwości realizacji nawet większej ilości zadań, które nie są krytyczne i terminy ich realizacji są późniejsze. Zaproponowano więc modyfikację strukturalnej miary wydajności (performance) na potrzebę identyfikacji kluczowych agentów, wiedzy i zasobów planowanego przedsięwzięcia.

Analizę kluczowych agentów, wiedzy i zasobów potrzebnych do realizacji planowanych zadań autor przeprowadził na przykładzie rewaloryzacji Dziedzińca Zewnętrznego wraz z drogami dojazdowymi. W celu określenia kluczowych środków produkcji do realizacji planowanego przedsięwzięcia w pierwszej kolejności usuwano pojedynczo z meta-sieci poszczególne węzły agenta i każdorazowo określono zmodyfikowaną przez autora niniejszego artykuł miarę wydajności dla otrzymanej meta-sieci. Taką samą procedurę zastosowano w przypadku węzłów wiedzy jak również zasobów z tą różnicą, że usuwano połączenia tych węzłów z węzłami agentów. Analiza przykładu potwierdziła zasadność proponowanego podejścia. Z przeprowadzonej analizy wynika, że liczba zadań, których nie można rozpocząć ze względu na brak dostępności danego agenta, wiedzy lub zasobu nie świadczy o kluczowym charakterze tych środków produkcji. O kluczowości agenta, wiedzy, czy zasobu w pierwszej kolejności decydują te zadania (z pośród tych zadań, które nie mogą być wykonane), które powinny być realizowane jako pierwsze zgodnie z najpóźniejszymi terminami ich rozpoczęcia.

W praktyce otrzymane wyniki mogą pomóc planiście w ocenie efektywności planu przedsięwzięcia. Informacje na temat kluczowych agentów, wiedzy oraz zasobów mogą stanowić podstawę do opracowania planów alternatywnych, bardziej odpornych na niepowodzenie w wyniku ewentualnej utraty kluczowych środków produkcji w trakcie realizacji przedsięwzięcia. 